\title{
RADIOCARBON UPDATES
}

\author{
Upcoming Conferences \\ Society for American Archaeology 70th Annual Meeting
}

The Society for American Archaeology will hold its annual meeting in Salt Lake City, Utah, USA, from March 30th to April 3rd, 2005. Papers may be submitted electronically; for directions, refer to the conference Web site, http://www.saa.org. Radiocarbon will be an exhibitor, so please stop in and see us.

\section{AMS 10th Annual Conference Circular}

The 10th International Conference on Accelerator Mass Spectrometry (AMS-10) is being hosted by the Lawrence Livermore National Laboratory's Center for Accelerator Mass Spectrometry (CAMS). The conference will take place from September 5th through 10th on the campus of the University of California at Berkeley. The purpose of the conference is to provide a forum for scientists to present and discuss recent developments in AMS technology and applications. The first circular is available on our Web site, http://www.radiocarbon.org/Announcements/AMS-10.pdf.

A special session on the "Reservoir Ages of the World Ocean: Progress and Prospect" has been proposed to coincide with the AMS-10 Conference in Berkeley. The proposed session would include presentations of the recent advances in the study of reservoir age corrections worldwide, both from pre-bomb known-age samples and reconstructions of past reservoir ages from a variety of methods (paired marine/terrestrial samples from middens or sediment cores, tree-ring vs. varve comparisons, U/Th-dated corals, sclerochronologically-dated marine corals and molluscs, etc.). Statistical considerations for $\Delta \mathrm{R}$ values and uncertainties in ${ }^{14} \mathrm{C}$ calibration would also be of interest.

If you are interested in participating, please contact Yaroslav V. Kuzmin (ykuzmin@tig.dvo.ru) or Paula J. Reimer (p.j.reimer@qub.ac.uk) with your possible topic of presentation as soon as possible, so they can put together an outline for the AMS Conference organizers.

\section{LSC 2005 Conference: Advances in Liquid Scintillation Spectrometry}

The Central Mining Institute will host the LSC 2005 Conference, and Radiocarbon will be publishing the proceedings of the conference. The conference will be held in Katowice, the capital city of Upper Silesia, Poland, from October 17-21, 2005. The organizers welcome you to present your achievements, to learn the latest developments of your colleagues, and to enjoy the traditional hospitality of the Polish people.

The main goal of the conference is to provide a forum for all scientists working in areas related to liquid scintillation counting and spectrometry (LSC). One of the objectives of the conference is to enable and promote the exchange of information, develop future directions in LSC, and give the opportunity to meet old and new friends. The conference organizers would like to pay particular emphasis to environmental studies and applications. Participation of young scientists and students is highly encouraged.

Please check the conference Web site (http://krzew.gig.katowice.pl/gig/lsc.php) for news and updates. Please email conference chairman Stanisław Chałupnik (lsc@gig.katowice.pl) for any further information. 
Australasian Archaeometry Conference 2005

The conference will be held at the Australian National University, Canberra, 12-15 December 2005, hosted by the Department of Archaeology and Natural History, RSPAS, and the Centre for Archaeological Research. The organizing committee invite sessions covering all aspects of scientific applications (biological, physical, and chemical sciences) in archaeology. Papers will be accepted until the end of February 2005. Proposals for technical workshops are also being sought and should include details of technical/space requirements. The organizing committee will consider theoretical and interpretative sessions as well as those discussing archaeometrical techniques. Sessions and papers usually focus on Australasia and the broader Asia-Pacific region, but sessions/papers by researchers working in other geographical areas will also be considered, especially if they have some relevance to work within the region (e.g. help to build up technical competency, etc.). Details will be regularly posted on the conference Web site: http://car.anu.edu.au/Archaeometry/ archaeometry_conference.html.

\section{9th International Radiocarbon Conference}

Conference organizers Christopher Bronk Ramsey and Tom Higham would like to announce dates for the 19th International Radiocarbon Conference which will be held in Oxford, at Keble College, from April 3-7, 2006. Further announcements about the conference will be sent out by email and posted on the conference Web site, http://www.rlaha.ox.ac.uk/orau/conference.html, and the Radiocarbon Web site, www.radiocarbon.org. 